\title{
ON THE SPEGIFICITY OF THE LEAD METHOD FOR PHOSPHORYLASE
}

\author{
Samuel H. HORI and Satoshi YONEZAWA \\ Department of Zoology, Hokkaido University, Sapporo 060 \\ Received for Publication March 30, 1973 \\ and in revised form May 24, 1973
}

\begin{abstract}
The specificity of the lead method for phosphorylase was investigated in rat liver by gel electrophoresis and biochemical and histochemical assays in comparison with the iodine method.

It was found that in the case of the iodine method, inhibition of amylase by ethylenediamine tetraacetate was necessary for a full demonstration of the phosphorylase activity, while in the lead method such interference of the phosphorylase staining by amylase was not a serious problem.

Phosphorylase was markedly inhibited by lead ions and glutaraldehyde, but quantitative and histochemical data indicated that glycogen synthesis could occur even in the presence of lead ions in frozen-substituted sections before and after fixation in glutaraldehyde.
\end{abstract}

$\alpha$-Glucan phosphorylase catalyses the synthesis and degradation of glycogen by transglucosylation from glucose 1-phosphate $(\mathrm{GlP})$. It is assayed by the amount of either inorganic phosphate liberated or glycogen synthesized from G1P.

Histochemical demonstration of this enzyme was first reported by Yin and Sun (33) in plant tissues, and Cobb (2) and Goldberg, Wade and Jones (8) in animal tissues. However, it was Takeuchi and his collaborators $(28,29)$ who established the method and studied extensively its location in animal tissues. In their method (the iodine method) the synthesized glycogen is demonstrated with Gram's iodine taking advantage of the difference of color reaction given by the newly synthesized and preexisted glycogen. Modifications of this method have been reported by several workers $(5-7,9-16,31)$.

On the other hand, an attempt to demonstrate the enzyme by trapping phosphates liberated from G1P using Gomori's acid phosphatase method (the lead method) was first made by Goldberg, Wade and Jones (8) and then by Deimling, Mölbert and Duspiva (4) and Hori $(15,18)$. The lead method has such theoretical drawbacks as: 1) although the phosphatase which specifically hydrolyzes G1P has not been reported in animal tissues, the presence of non-specific phosphatase acting on G1P can not be denied. In fact, the G1P hydrolyzing activity is demonstrated in brush borders of renal convolutions and microvilli of intestinal mucous epithelium in the rat, and this non-specific activity can not be inhibited by a high concentration of NaF. 2) Adenosine 5'-phosphate (AMP), a potent activator of phosphorylase can not be used, when the AMP hydrolyzing activity 
of tissues is high, as in the liver. 3) Lead ions are very inhibitory to the phosphorylase. 4) Tissues have a tendency to bind lead non-specifically. For these reasons, the lead method is by no means superior to the iodine method. However, it seems to be useful under certain conditions, particularly when the enzyme be demonstrated at a fine structural level.

In the present study, the specificity of the lead method was re-examined in rat liver by means of disc electrophoresis and chemical assay in comparison with the iodine method.

\section{MATERIALS AND METHODS}

Rats used were male adults of Wistar-King A strain. Protein was assayed according to the method of Lowry, Rosebrough, Farr and Randall (23).

Electrophoretic studies: Livers were perfused with $0.25 \mathrm{M}$ sucrose, and homogenized with two volumes of $48 \mathrm{mM}$ HCl-imidazole buffer, $\mathrm{pH} 5.8$ containing $20 \mathrm{mM} \mathrm{NaF}$ and $20 \mathrm{mM}$ ethylenediamine tetraacetate (EDTA). The homogenate was centrifuged at $18,000 \mathrm{~g}$ for $30 \mathrm{~min}$ and the supernatant was subjected to electrophoresis at a dose of $15 \mu \mathrm{l}(740 \mu \mathrm{g}$ protein) per column. In some cases the homogenate was brought to $\mathrm{pH} 5.6$ by the addition of $2 \mathrm{~N}$ acetic acid and centrifuged. The supernatant was treated with ammonium sulfate $(2.5 \mathrm{~g}$ per $10 \mathrm{ml})$ and centrifuged. To $10 \mathrm{ml}$ of the resulting supernatant was added $1 \mathrm{~g}$ ammonium sulfate and the precipitate was collected. This precipitate was dialyzed against $12 \mathrm{mM} \mathrm{HCl}$-imidazole buffer containing $50 \mathrm{mM} \mathrm{NaF}$ and $5 \mathrm{mM}$ EDTA, pH 6.5 , and the dialyzed material (AS 35 sample) was subjected to electrophoresis at a dose of $180 \mu \mathrm{g}$ protein per column.

For preparation of a sample with branching enzyme activity, perfused livers were homogenized with two volumes of distilled water and centrifuged at $18,000 \mathrm{~g}$ for $30 \mathrm{~min}$. The supernatant (brancher sample) had a high branching enzyme activity, and a very low phosphorylase activity.

Polyacrylamide gel electrophoresis was carried out according to the method of Davis, Schliselfeld, Wolf, Leavitt and Krebs (3) modified as follows: small pore gel consisted of $7.5 \%$ acrylamide, $0.2 \%$ methylenebisacrylamide, $10 \mathrm{mM}$ HCl-tris buffer, $\mathrm{pH}$ 8.9, $0.001 \%$ shellfish glycogen (Nakarai Chemicals, Ltd.), and spacer and sample gels consisted of $3.3 \%$ acrylamide, $0.83 \%$ methylenebisacrylamide, $8 \mathrm{mM}$ HCl-imidazole buffer, $\mathrm{pH}$ 7.3. Gels were cast in columns $(3 \times 12 \times$ $100 \mathrm{~mm}$ ) and electrophoresed at $4^{\circ} \mathrm{C}$ at a constant current of $0.75 \mathrm{~mA}$ per column. Following electrophoresis, each gel was sliced into four strips and was stained for phosphorylase and amylase.

For phosphorylase, the gels were incubated for $60 \mathrm{~min}$ at $37^{\circ} \mathrm{C}$ in Media I, II or IV (Table 1) with or without $0.5 \mathrm{mM}$ AMP. In some cases, G1P of Medium IV was replaced by an equimolar concentration of $\beta$-glycerophosphate in order to see if a non-specific acid phosphatase activity could be demonstrated in the gels.

After incubation, the gels were stained by Lugol's iodine solution in the case of the gels incubated in Medium I or II and by ammonium sulfide in the cases of the gels incubated in Medium IV. The gels were washed in running tap water overnight prior to staining with ammonium sulfide. 
TABLE 1 Composition of incubation media

\begin{tabular}{lccccc}
\hline \multicolumn{1}{c}{ Components } & \multicolumn{5}{c}{ Medium } \\
\cline { 2 - 6 } & I & II & III & IV & V \\
\hline Acetate buffer, $90 \mathrm{mM}, \mathrm{pH} 5.8$ & + & + & + & + & + \\
$\mathrm{EDTA}, 20 \mathrm{mM}$ & + & - & + & - & - \\
$\mathrm{NaF}, 20 \mathrm{mM}$ & + & + & - & + & + \\
$\mathrm{GlP}, 4.2 \mathrm{mM}$ & + & + & + & + & - \\
$\mathrm{Pb}\left(\mathrm{NO}_{3}\right)_{2}, 3.6 \mathrm{mM}$ & - & - & - & + & + \\
\hline
\end{tabular}

Effects of $\mathrm{pH}$ of the incubating medium on phosphorylase activity were examined using $0.1 \mathrm{M}$ acetate buffer ( $\mathrm{pH} 5.0$ to 5.8), 0.1 M HCl-imidazole buffer ( $\mathrm{pH} 6.0$ to 7.5 ) and $0.1 \mathrm{M}$ glycine- $\mathrm{NaOH}$ buffer ( $\mathrm{pH} 8.2$ to 10.5 ).

For demonstration of the amylase the gels were incubated at $37^{\circ} \mathrm{C}$ for $90 \mathrm{~min}$ in $0.1 \mathrm{M}$ acetate buffer, $\mathrm{pH} 5.8$, containing $5 \%$ corn starch with or without $\mathrm{KCl}$, $\mathrm{CaCl}_{2}$ or EDTA at concentrations of $20 \mathrm{mM}$ and $50 \mathrm{mM}$, rinsed in water briefly and then incubated again at $25^{\circ} \mathrm{C}$ in the same incubation medium from which corn starch was omitted. After $30 \mathrm{~min}$, the gels were stained in Lugol's solution.

Quantitative studies: Liver was sliced into cubes having a sectional area of approximately $0.5 \mathrm{~cm}^{2}$, frozen in dry ice chilled acetone, sectioned in a cryostat at $15 \mu$ and substituted in acetone at $-70^{\circ} \mathrm{C}$ for 2 days. Sections were then mounted on coverslips with celloidine, as reported previously (17). In a preliminary experiment, fresh-frozen sections were used for quantitative studies, but the results varied considerably from experiment to experiment, particularly when dealing with phosphorylase. On the other hand, frozen-substituted sections always gave consistent results.

Twenty perfect, consecutive sections were divided into 4 or 5 groups consisting of every 5 or 4 sections, and the groups were subjected to different experiments. For examination of effects of glutaraldehyde fixation on the phosphorylase activity, the first group was directly assayed for pre-existed glycogen, and the second was incubated in Medium I, while the third to the fifth were fixed for $15 \mathrm{~min}$ at $2{ }^{\circ} \mathrm{C}$ in $0.25 \%, 0.5 \%$ and $1 \%$ glutaraldehyde in $0.1 \mathrm{M}$ cacodylate buffer, $\mathrm{pH} 7.4$, respectively, rinsed in cold $50 \mathrm{mM}$ acetate buffer, $\mathrm{pH} 5.8$ and then incubated in Medium I or III. The experiment was repeated at least 3 times using different sets of sections. Likewise, effects of EDTA and $\mathrm{Pb}$ ions were examined by assaying the first group for pre-existed glycogen, and the second to fifth for glycogen contents after incubation in Media I, II, IV and V, respectively. A similar experiment was also carried out with sections fixed with $0.25 \%$ glutaraldehyde for $15 \mathrm{~min}$ at $2^{\circ} \mathrm{C}$. Experiments on amylase were carried out in a similar manner.

Phosphorylase assay: Incubation media used were listed in Table 1. Each incubated section was placed in a test tube and digested with $1 \mathrm{ml}$ of $30 \% \mathrm{KOH}$ by heating $15 \mathrm{~min}$ in boiling water. After cooling, $1.2 \mathrm{ml}$ of $95 \%$ ethanol was added and the mixture was allowed to stand overnight at $37^{\circ} \mathrm{C}$. It was then centrifuged and the sediment was taken up with $1 \mathrm{ml}$ of water and mixed with 
$5 \mathrm{ml}$ of the anthrone reagent $\left(0.05 \%\right.$ anthrone and $1 \%$ thiourea in $\left.72 \% \mathrm{H}_{2} \mathrm{SO}_{4}\right)$. It was heated $15 \mathrm{~min}$ in boiling water and optical density was read at $615 \mathrm{~nm}$ against reagent blank. Glycogen contents of sections were calculated using rat liver glycogen as standard and expressed as percentage of the glycogen content of unincubated sections.

Amylase assay: Amylase activity was measured according to the method of Rutter and Brosemer (27). The standard incubation medium was composed of $60 \mathrm{mM}$ acetate buffer, $\mathrm{pH} 5.8,0.056 \%$ soluble starch and $20 \mathrm{mM} \mathrm{CaCl}$. Effects of EDTA (20 and $50 \mathrm{mM}$ ) and lead nitrate $(1.2 \mathrm{mM}$ and $3.6 \mathrm{mM}$ ) were examined by adding them to the incubating medium. Effects of glutaraldehyde fixation were examined in the same manner as for phosphorylase.

Each section was incubated in a test tube for $15 \mathrm{~min}$ at $37^{\circ} \mathrm{C}$. After incubation, an $0.5 \mathrm{ml}$ aliquot of the medium was added to $0.25 \mathrm{ml}$ of $8 \mathrm{mM} \mathrm{I}_{2}-24 \mathrm{mM} \mathrm{KI}$ solution and diluted to $4 \mathrm{ml}$ with distilled water. Optical density was read at $550 \mathrm{~nm}$ against iodine solution similarly diluted and the amount of starch hydrolyzed was calculated using soluble starch as standard. The result was expressed as percentage of the amount of starch hydrolyzed by unfixed sections incubated in the standard incubation medium.

Histochemical studies: Frozen-substituted sections were incubated in Media I, II and IV before and after fixation in $0.25 \%$ glutaraldehyde in $0.1 \mathrm{M}$ cacodylate buffer, $\mathrm{pH} 7.4$ for $15 \mathrm{~min}$ at $2^{\circ} \mathrm{C}$. After incubating for $1 \mathrm{hr}$ at $37^{\circ} \mathrm{C}$, sections treated with Medium IV were washed three times with distilled water and immersed in dilute ammonium sulfide solution. In some cases, sections were first preincubated for $30 \mathrm{~min}$ at $37^{\circ} \mathrm{G}$ in $0.1 \mathrm{M}$ acetate buffer, $\mathrm{pH} 5.8$ with or without $20 \mathrm{mM} \mathrm{NaF}$ and then in Medium I or IV for $1 \mathrm{hr}$ at $37^{\circ} \mathrm{C}$. Sections incubated with Media I and II were directly stained with Lugol's solution.

Frozen sections of liver slices ( $1 \mathrm{~mm}$ thick) which had been fixed in $2 \%$ glutaraldehyde and $6 \%$ glucose in $0.1 \mathrm{M}$ cacodylate buffer, $\mathrm{pH} 7.4$ for $2 \mathrm{hr}$ at $2^{\circ} \mathrm{C}$ were stained by the iodine and lead methods. Phosphorylase activity was most intense in the intermediate area of a few cells thickness, moderate in the outer and none at all in the inner area (Fig. 15). Observations were therefore made on the outer area showing good morphology.

\section{RESULTS}

Electrophoretic studies: With the iodine method, the hepatic phosphorylase was demonstrated as a single purple band on the gels (Fig. la). Removal of AMP from the incubation medium resulted in a slight but definite decrease of the activity without a change in color. The hue of the phosphorylase band appeared to be affected by the activity of branching enzyme present in the enzyme sample; i.e., the AS 35 sample which was obtained by ammonium sulfate fractionation of the crude enzyme sample contained a blue band, while the addition of the brancher sample $(10 \mu \mathrm{l})$ to the AS 35 sample $(120 \mu \mathrm{g}$ protein) before electrophoresis changed the color of the band to brown. In addition, when the AS 35 sample was first electrophoresed and then incubated in the medium supplemented with the brancher sample ( $50 \mu \mathrm{l}$ per ml medium), the band was now stained brown at the surface and blue in the center. Furthermore, the phosphorylase band from 
the crude sample stained blue at $\mathrm{pH} 5.3$ at which the branching enzyme was inactivated (19), but stained purple in the range from $\mathrm{pH} 5.5$ to 8.8 and brown at $\mathrm{pH} 9.5$.

When the gels were incubated without EDTA(Medium II) the phosphorylase band became narrower (Fig. 1b). Since this seemed to be due to the presence of amylase in the band, demonstration of the amylase on the gels was attempted. As a result, three distinct molecular forms of amylase were detected in liver homogenates (Fig. 1e), and designated I-III in the increasing order of anodal mobility. The mobility of band II enzyme was the same as that of phosphorylase. The three isozymes differed in the reactivity to activators and inhibitors; EDTA was inhibitory to all the three isozymes (Fig. If), while $\mathrm{KCl}$ and $\mathrm{CaCl}_{2}$ stimulated amylases I and II only (Fig. Id). Plasma contained amylase I, but the hepatic

\section{Phos phorylase}

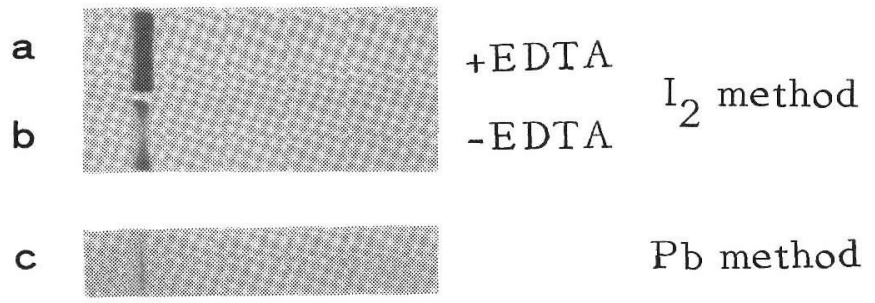

Amylase

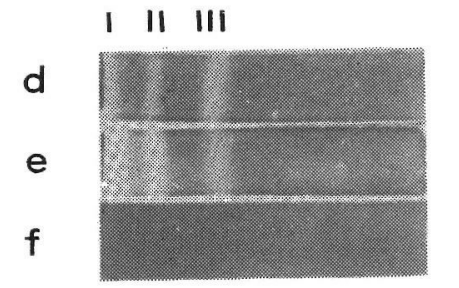

$$
\begin{aligned}
& -\mathrm{CaCl}_{2} \\
& +\mathrm{CaCl}_{2} \\
& +\mathrm{EDTA}
\end{aligned}
$$

Fig. 1, a-c. Phosphorylase zymograms of rat liver homogenates. a, gel was incubated $60 \mathrm{~min}$ at $37^{\circ} \mathrm{C}$ with $4.2 \mathrm{mM}$ GIP and $20 \mathrm{mM}$ EDTA and stained with Lugol's iodine solution. b, same as a, but without EDTA. c, gel was incubated $60 \mathrm{~min}$ at $37^{\circ} \mathrm{C}$ with $4.2 \mathrm{mM}$ GIP and $3.6 \mathrm{mM}$ lead nitrate and stained with dilute ammonium sulfide solution. When G1P was replaced by $\beta$-glycerophosphate, no band was detected.

FIG. 1, d-f. Amylase zymograms of rat liver homogenates.

$\mathrm{d}$, gel was incubated first with $5 \%$ corn starch in $0.1 \mathrm{M}$ acetate buffer, pH 5.8 for $90 \mathrm{~min}$ at $37^{\circ} \mathrm{C}$ and then with acetate buffer for $30 \mathrm{~min}$ at $25^{\circ} \mathrm{C}$ and stained with Lugol's solution. e, same as $\mathrm{d}$, but with $20 \mathrm{mM} \mathrm{CaCl}_{2}$ in acetate buffer. f, same as d, but with $50 \mathrm{mM}$ EDTA in acetate buffer. Note that band II migrates as fast as the phosphorylase band, and that $\mathrm{CaCl}_{2}$ activates bands I and II only. 
amylase I was present even in the liver perfused with sucrose. Therefore, all three isozymes would be native to this organ. These findings were in good agreement with the biochemical data in literature $(1,24,25)$.

With the lead method for phosphorylase, liver homogenates prepared in the presence of $\mathrm{NaF}$ exhibited one band at the same position as that revealed with the iodine method (Fig. 1c).

When the lead concentration of incubation medium was decreased from $3.6 \mathrm{mM}$ to $1.2 \mathrm{mM}$ the band was stained more intensely, while addition of $\mathrm{NaF}$ (20 or $50 \mathrm{mM}$ ) did not affected the stainability. On the other hand, no band was detected when G1P was replaced by $\beta$-glycerophosphate, thus proving that the activity demonstrated by the lead method could not be ascribed to a non-specific phosphatase.

Quantitative studies: Fig. 2 shows effects of EDTA and lead ions on the amount of glycogen contained in sections after incubation. As is clearly shown, the glycogen content was extremely low in sections incubated without EDTA (Medium II) when compared with those with EDTA (Medium I). On the other hand, more than one half of the total glycogen was lost from sections following incubation in Media IV and V. Such loss of glycogen was partially prevented by fixation. The difference in glycogen recovery between Media IV and V might be explained in terms of glycogen synthesis by phosphorylase, since it was unlikely that GlP inhibited the glycogen degradation by amylase, and that omission of G1P initiated the glycogen degradation by phosphorylase in the phosphate-free medium.

Fig. 3 shows effects of glutaraldehyde fixation and of $\mathrm{NaF}$ on the glycogen content. It was concluded from these data that the phosphorylase phosphatase was almost completely inhibited by $0.25 \%$ glutaraldehyde, while the phosphorylase

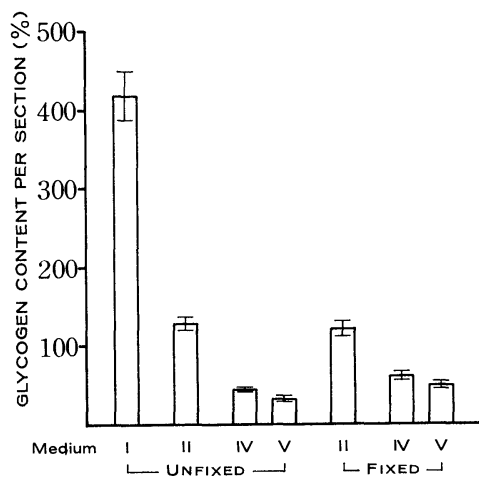

FIG. 2.

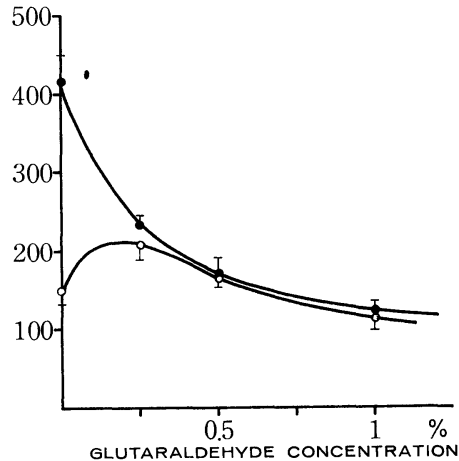

FIG. 3.

Fig. 2. Glycogen contents (mean \pm S. E.) of unfixed and $0.25 \%$ glutaraldehyde-fixed, frozen-substituted sections after $60 \mathrm{~min}$ incubation in Media I, II, IV and V. $100=17 \mu \mathrm{g}$ glycogen per section.

Fig. 3. Glycogen contents (mean \pm S. E.) of frozen-substituted sections which were fixed $15 \mathrm{~min}$ at $2^{\circ} \mathrm{C}$ with $0,0.25,0.5$ and $1 \%$ glutaraldehyde in $0.1 \mathrm{M}$ cacodylate buffer, $\mathrm{pH} 7.4$ and incubated $60 \mathrm{~min}$ at $37^{\circ} \mathrm{C}$ in Medium I (- - ) and in Medium III (- - ). $100=17 \mu \mathrm{g}$ glycogen per section. 


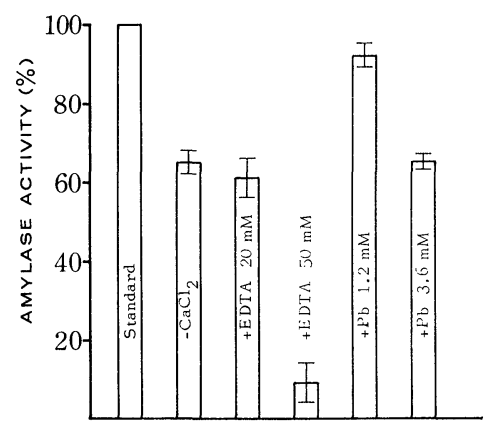

Fig. 4.

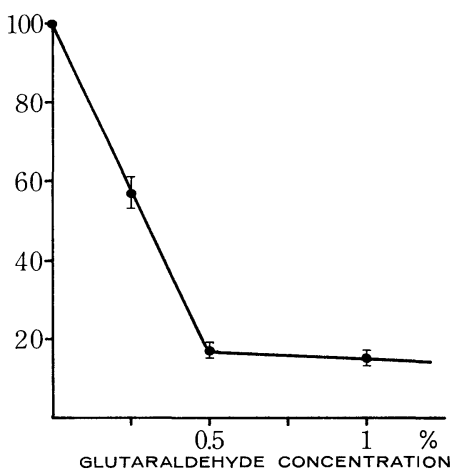

Fig. 5.

FIG. 4. Amylase activity (mean \pm S. E.) of frozen-substituted sections, which were incubated $15 \mathrm{~min}$ at $37^{\circ} \mathrm{C}$ with or without $\mathrm{CaCl}_{2}$ or EDTA or $\mathrm{Pb}$ ions. Standard incubation medium contained $0.056 \%$ soluble starch and $20 \mathrm{mM} \mathrm{CaCl}_{2}$ in $60 \mathrm{mM}$ acetate buffer, $\mathrm{pH} 5.8 . \quad 100=502 \mu \mathrm{g}$ soluble starch hydrolyzed per $15 \mathrm{~min}$ per section.

FIg. 5. Amylase activity (mean \pm S. E.) of frozen-substituted sections which were fixed $15 \mathrm{~min}$ at $2^{\circ} \mathrm{C}$ with $0,0.25,0.5$ and $1 \%$ glutaraldehyde and incubated $15 \mathrm{~min}$ at $37^{\circ} \mathrm{C}$ in the standard incubation medium. $\quad 100=565$ $\mu \mathrm{g}$ soluble starch hydrolyzed per $15 \mathrm{~min}$ per section.

was still active, though considerably inhibited, after fixation in 1\% glutaraldehyde.

Fig. 4 shows effects of $\mathrm{CaCl}_{2}$, EDTA and lead ions on amylase activity. $\mathrm{CaCl}_{2}$ was apparently stimulative to the enzyme, but its effect was nullified by the equimolar concentration of EDTA. Lead ions were also inhibitory; increase of lead concentration from $1.2 \mathrm{mM}$ to $3.6 \mathrm{mM}$ caused a four-fold inhibition of the enzyme.

Fig. 5 shows that glutaraldehyde was extremely inhibitory to the amylase.

Histochemical studies: Frozen-substituted sections incubated with EDTA and stained by iodine exhibited a stronger reaction in centrolobular areas than in periportal areas (Fig. 7). The intracellular distribution of the reaction product seemed to coincide with that of glycogen; i.e., it was rather evenly distributed throughout the cytoplasm in centrolobular areas, but it was in the form of aggregates scattered in the cytoplasm in periportal areas. A similar staining feature was also obtained with the lead method (Figs. 10 and 11). These findings agreed well with our previous data (15-17).

Omission of EDTA from the incubation medium resulted in a striking decrease of the iodine reaction, particularly in centrolobular areas (Figs. 8 and 9), suggesting that the hepatic amylase would be more active in centrolobular areas than in periportal areas.

Following preincubation in acetate buffer sections became unreactive to both the lead and iodine methods, while the reactivity was unchanged when $\mathrm{NaF}$ was added to the acetate buffer. This seemed to indicate that NaF protected the phosphorylase from inactivation by the phosphorylase phosphatase during preincubation.

Frozen sections of glutaraldehyde-fixed tissues were stained similarly by the iodine and lead methods (Figs. 12-14), though the stainability was less intense than 
that of frozen-substituted sections. To be noted was the finding that glutaraldehydefixed, frozen sections were stainable with either iodine or ammonium sulfide to a similar extent after incubation in the lead medium (Figs. 12 and 13).

\section{DISGUSSION}

In order to study effects of chemicals on the enzyme at a histochemical level it is necessary to examine whether the enzyme in question exists in a single or multiple molecular forms, since they might differ from each other in response to chemicals. For this reason, the phosphorylase was first studied electrophoretically in the present study.

The results of electrophoresis indicated that the hepatic phosphorylase existed in a single molecular form which was demonstrable with either the iodine or the lead method, and that liver homogenates prepared in the presence of $20 \mathrm{mM} \mathrm{NaF}$ did not exhibit $\beta$-glycerophosphate hydrolyzing activity after electrophoresis. These findings were favorable for the specificity of the lead method.

The present electrophoretic and quantitative studies also furnished evidence and thus substantiated our previous results that the demonstration of hepatic phosphorylase with the iodine method was hindered by the presence of amylase unless EDTA was added to the incubation medium. This explained why the phosphorylase was demonstrated only weakly in the absence of EDTA in frozensubstituted sections.

Figs. 6-11. Frozen-substituted sections of rat liver stained for phosphorylase. All photographs were taken and processed under the same condition in order to show the relative intensity of reaction. c, central vein; $p$, portal vein. $\times 100$.

Figs. 6, 7. Unfixed and $0.25 \%$ glutaraldehyde-fixed sections incubated $60 \mathrm{~min}$ at $37^{\circ} \mathrm{C}$ with $20 \mathrm{mM}$ EDTA and stained with Lugol's solution, respectively. It was clearly shown in Fig. 7 that the centrolobular area was reacted more intensely than the periportal area. The same phenomenon was also observed in Fig. 6, but it was not well reproduced here because of the very high enzyme activity.

Figs. 8, 9. Unfixed and $0.25 \%$ glutaraldehyde-fixed sections incubated without EDTA and stained with Lugol's solution, respectively. The reaction was confined in periportal cells, suggesting that the amylase was more active in centrolobular areas than in periportal areas.

Figs. 10,11. Unfixed and $0.25 \%$ glutaraldehyde-fixed sections incubated with $3.6 \mathrm{mM}$ lead nitrate and stained with dilute ammonium sulfide solution, respectively. Although the reaction intensity was reduced after fixation, the lobular pattern of the reaction was the same in unfixed and fixed sections, being more active in centrolobular areas than in periportal areas.

Figs. 12-15. Frozen sections of rat liver fixed $2 \mathrm{hr}$ at $2{ }^{\circ} \mathrm{C}$ with $2 \%$ glutaraldehyde and $6 \%$ glucose in $0.1 \mathrm{M}$ cacodylate buffer, $\mathrm{pH}$ 7.4. Figs. 12,13 , sections incubated $60 \mathrm{~min}$ at $37^{\circ} \mathrm{C}$ with GIP, $\mathrm{NaF}$ and $\mathrm{Pb}$ and stained with Lugol's solution and dilute ammonium sulfide solution, respectively. The result indicates that the glycogen synthesis occurs in the presence of $3.6 \mathrm{mM} \mathrm{Pb}$ after glutaraldehyde fixation. $\times 100$.

Fig. 14. Section incubated with GIP, NaF and EDTA and stained with Lugol's solution. The reaction was only slightly intenser than that of Fig. 12, suggesting that the enzyme became less sensitive to lead ions after fixation. $\times 100$.

FIg. 15. Section incubated with GIP, NaF and EDTA and stained with Lugol's solution showing gxation firadient. $\times 40$. 

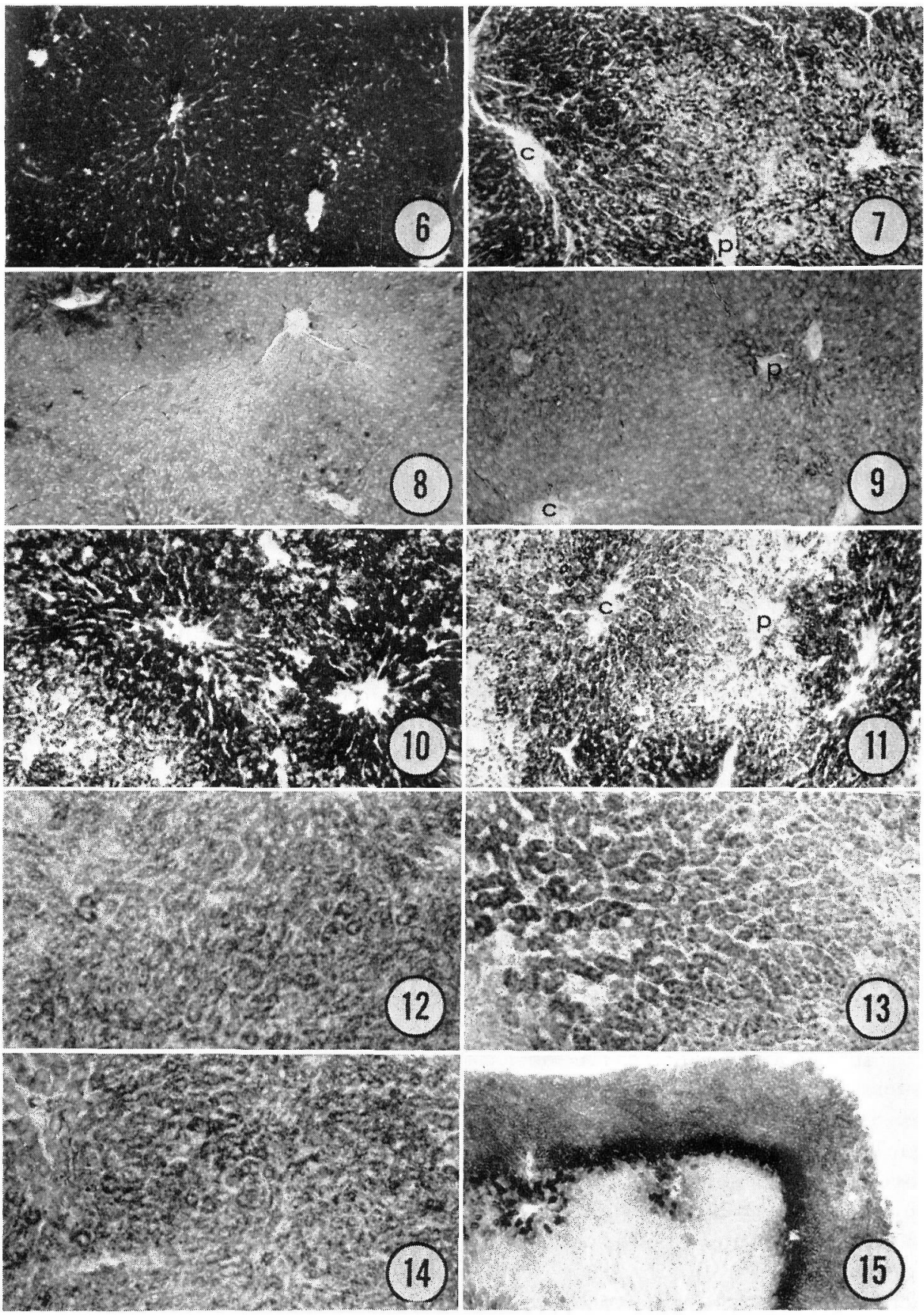
It was however uncertain whether the presence of amylase, and thus the degradation of glycogen would affect directly the activity of phosphorylase, since it was technically difficult to assay the glycogen synthesis by phosphorylase and the glycogen breakdown by amylase separately. It was also for this reason that the effect of lead ions on phosphorylase could not be quantitated, though their inhibitory action was evident (Fig. 2).

The amount of glycogen recovered from sections after incubation in the medium containing lead ions (Media IV and V) was much less than that originally existed in the sections. This was apparently due to the inhibition of phosphorylase by lead ions and the stimulation of amylase in the absence of EDTA. A question thus arose whether the phosphorylase would be still active to a demonstrable extent even under such a condition that one half of the pre-existed glycogen was degraded by the amylase, and in other words, if the phosphorylase could be demonstrated by the lead method.

The first answer to this question was given by the quantitative data that the glycogen recovery was about 10\% higher in the medium containing G1P (Medium IV) than in the medium devoid of G1P (Medium V) (Fig. 2).

The second answer which seemed to be more clear-cut was given by the histochemical finding that frozen sections of glutaraldehyde-fixed tissues showed a positive reaction to both iodine and ammonium sulfide after incubation in Medium IV which contained lead and no EDTA. These findings clearly indicated that the presence of lead ions in the incubation medium did not render the histochemical demonstration of phosphorylase impossible, and that fixation in glutaraldehyde might be more inhibitory to the amylase than to the phosphorylase. It would be such a peculiar effect of glutaraldehyde that rendered phosphorylase staining by the lead method possible in fixed tissues (18).

Recently, Wang and Tu (32) studied the modification of muscle phosphorylase b by glutaraldehyde and found that the enzyme modified by glutaraldehyde was considerably more resistant than native phosphorylase $b$ toward heat, cold, or urea denaturation. Although the hepatic phosphorylase differs in several respects from the muscle phosphorylase, the former might also be so modified by glutaraldehyde as to become resistant to various treatment as suggested by the present data.

The present finding that sections were reactive to ammonium sulfide as well as iodine after preincubation with $\mathrm{NaF}$, but not without $\mathrm{NaF}$ gave support to the specificity of the lead method, since the presence of such phosphatases that are active only in the presence of $\mathrm{NaF}$ has not been known.

In the absence of EDTA the iodine method stained periportal areas more intensely than centrolobular areas in frozen-substituted sections, in contrast to the result obtained with the lead method. Lindberg and Palkama (20-22) regarded such discrepancy in the staining pattern as an indication that the lead method was dealing with an unspecified phosphatase. However, it would be simply explained if one assumes that the amylase might be more active in centrolobular areas than in periportal areas. In fact, Tremblay (30) reported that this was the case. For this reason, it became very difficult to demonstrate phosphorylase activity in centrolobular areas when the iodine method was employed without EDTA. On the other hand, it is phosphate, but not glycogen that the lead method demonstrates, so that the result would be less affected by the presence of amylase. 
Thus, the lead method stained centrolobular areas more intensely than periportal areas.

In view of the marked inhibitory effect of lead ions on phosphorylase, the lead method could not be superior to the iodine method. However, it seemed reasonable to assume that the lead method would be reliable if used under carefully controlled conditions, and that the method might only suffer from the same, but not other kind of non-specificity as did other metal precipitation methods for enzymes.

Use of EDTA for phosphorylase histochemistry was first proposed by Godlewski (6) with a purpose to stabilize the enzyme. The efficacy of EDTA was however proven in the previous and present studies to be due to its inhibitory action on the amylase (17). In other words, EDTA might be least effective if applied to tissues having little amylase activity, as Miyayama (26) recently reported with skeletal muscles.

\section{REFERENCES}

1. Brosemer, R. W. and Rutter, W.J.: Liver amylase I. Cellular distribution and properties. J. Biol. Chem. 236; 1253, 1961.

2. Cobb, J. D.: Relation of glycogen, phosphorylase and ground substance to calcification of bone. Arch. Pathol. 55; 496, 1953.

3. Davis, C. H., Schliselfeld, L. H., Wolf, D. P., Leavitt, G. A. and Krebs, E. G.: Interrelationships among glycogen phosphorylase isozymes. J. Biol. Chem. 242; 4824, 1967.

4. Deimling, O., Mölbert, E. R. G. and Duspiva, F.: Electron microscope identification of glucose 1-phosphate hydrolyzing enzymes in the heart muscle of the albino rat. Beitr. Pathol. $123 ; 127,1960$.

5. Eränkö, O. and Palkama, A.: Improved localization of phosphorylase by the use of polyvinyl pyrrolidone and high substrate concentration. J. Histochem. Cytochem. 9; 585, 1961.

6. Godlewski, H. G.: Application of ethylenediamine tetraacetic acid (EDTA) in the histochemical method for demonstration of phosphorylase and branching enzyme. Bull. Acad. Pol. Sci. 8; 441, 1960.

7. Godlewski, H. G.: Are active and inactive phosphorylases histochemically distinguishable? J. Histochem. Cytochem. 11; 108, 1963.

8. Goldberg, O. B., Wade, O. R. and Jones, H. W.: Polysaccharide synthesis in frozen tissue sections as a histochemical method for phosphorylase. J. Natl. Cancer Inst. 13; 543, 1952.

9. Grillo, T. A. I.: Histochemical demonstration of liver phosphorylase. J. Histochem. Cytochem. $8 ; 322,1960$.

10. Grillo, T. A. I.: A histochemical study of phosphorylase in the tissue of the chick embryo. J. Histochem. Cytochem. 9; 386, 1961.

11. Guha, S. and Wegmann, R.: Etudes sur l'activite phosphorylasique. I. Une nouvelle methode de mise en evidence de la phosphorylase. Ann. Histochim. 4; 103, 1959.

12. Guha, S. and Wegmann, R.: Ditto IV. Activation in vitro par la protamine. Ann. Histochim. 5; 1, 1960.

13. Guha, S. and Wegmann, R.: The use of $\mathrm{C}^{14}$ labelled substrate in histochemical demonstration of different forms of phosphorylase. Histochemie 6; 350, 1966.

14. Guha, S. and Wegmann, R.: Phosphorylase in chick-embryo liver. J. Histochem. Cytochem. 9; 454, 1961.

15. Hori, S. H.: Cytological phosphorylase locations in rat liver and muscle as shown by a lead precipitation method. Stain Technol. 39; 375, 1964.

16. Hori, S. H.: Use of ethylenediamine tetraacetic acid in the cytologic demonstration of amylophosphorylase. Stain Technol. 40;157, 1965. 
17. Hori, S. H.: Effect of EDTA on histochemical demonstration of phosphorylase activity. $J$. Histochem. Cytochem. 14; 501, 1966.

18. Hori, S. H.: Fine structural locations of $\alpha$-glucan phosphorylase, as shown by lead precipitation and electron microscopy. Stain Technol. 41; 91, 1966.

19. Larner, J.: Branching enzyme from liver: amylo-1,4-1,6-transglucosidase. Methods in Enzymology, ed. by S. P. Colowick and N. O. Kaplan, Academic Press, New York and London, $1 ; 222,1955$.

20. Lindberg, L. A. and Palkama, A.: Methodological observations on the histochemical demonstration of glycogen phosphorylase activity. Ann. Med. Exp. Biol. Fenn. 48; 67, 1970.

21. Lindberg, L. A. and Palkama, A.: Histochemical demonstration of phosphorylase with lead technique; real or artifact. Scand. J. Clin. Lab. Invest. 25; suppl 113, 1970.

22. Lindberg, L. A. and Palkama, A.: The effect of some factors on the histochemical demonstration of liver glycogen phosphorylase activity. J. Histochem. Cytochem. 20; 331, 1972.

23. Lowry, O. H., Rosebrough, N.J., Farr, A. L. and Randall, R. J.: Protein measurement with the Folin phenol reagent. J. Biol. Chem. 193; 265, 1951.

24. McGeachin, R. L., Gleason, J. R. and Adams, M. R.: Amylase distribution in extrapancreatic, extra salivary tissues. Arch. Biochem. Biophys. 75; 403, 1958.

25. McGeachin, R. L. and Potter, B. A.: Amylase in isolated liver cells. J. Biol. Chem. 235; 1354, 1960.

26. Miyayama, H.: Validity of iodine procedure of histochemical methods for phosphorylase in skeletal muscle fibers. Acta histochem. cytochem. 4; 87, 1971.

27. Rutter, W. J. and Brosemer, R. W.: Glucose production by isolated rat liver cells. An amylase-oligoglucosidase pathway for glycogen breakdown. J. Biol. Chem. 236; 1247, 1961.

28. Takeuchi, T., Higashi, K. and Watanuki, S.: Distribution of amylophosphorylase in various tissues of human and mammalian organs. J. Histochem. Cytochem. 3; 485, 1955.

29. Takeuchi, T. and Kuriaki, H.: Histochemical detection of phosphorylase in animal tissues. J. Histochem. Cytochem. 4; 153, 1955.

30. Tremblay, G.: The localization of amylase activity in tissue sections by a starch film method. J. Histochem. Cytochem. 11; 202, 1963.

31. Verne, J., Guha, S., Petkov, P. and Wegmann, R.: Effect in vivo du glucagon sur le glycogene et sur la phosphorylase hepatique du lapin. Ann. Histochim. 6; 137, 1961.

32. Wang, J.H.-C. and Tu, J.-I.: Modification of glycogen phosphorylase b by glutaraldehyde. Preparation and isolation of enzyme derivatives with enhanced stability. Biochemistry 8; 4403. 1969.

33. Yin, H. G. and Sun, C. N.: Histochemical method for detection of phosphorylase in plant tissues. Science $105 ; 650,1947$. 